\title{
Teacher Engagement Mediates Self-Efficacy and Classroom Management: Focus on Indonesian Primary Schools
}

\author{
Anisa Rahmadani ${ }^{1}$, Farida Kurniawati $^{1}$
}

${ }^{1}$ Faculty of Psychology, Universitas Indonesia, Jakarta

\section{Indonesia}

Correspondencia: Farida Kurniawati. Faculty of Psychology. Universitas Indonesia, Jl. Lkr. Kampus Raya, Depok, Jawa Barat 16424. E-mail: farida1@ui.ac.id

(C) Universidad de Almería and Ilustre Colegio Oficial de la Psicología de Andalucía Oriental (Spain) 


\begin{abstract}
Introduction. The numbers of students with special needs studying in regular classes is increasing every year. This increase has consequences for teachers, who must manage classrooms to meet the students' diverse needs and characteristics. The contributing factor to successful inclusive education is teachers' self-efficacy in practicing it. Successful implementation of inclusive education, on the other hand, classroom management can be viewed as performance influenced by the extent to which teachers are involved in their work, that is, teachers' "engagement."
\end{abstract}

Method. This quantitative correlational study aimed to determine whether teachers' engagement mediates self-efficacy in inclusive practice and classroom management. A total of 242 inclusive primary school teachers in DKI Jakarta-Indonesia, completed three self-report questionnaires.

Results. Teachers' engagement significantly acts as mediator in the correlation between teachers' self-efficacy and their classroom management.

\title{
Discussion and Conclusion.
}

Using motivational process in the job-demand model, results show that teachers' self-efficacy functions as a personal resource in implementing inclusive education. This means that teachers' self-efficacy conducted by teachers first raises the condition of the teacher involved in the role of work, before finally influencing the extent to which the teacher managed the classroom. Therefore that overall student, including students with special needs, get the optimal educational benefits.

Keywords: classroom management; inclusive education; primary school; self-efficacy; teacher engagement. 


\section{Resumen}

Introducción. El número de estudiantes con necesidades especiales que estudian en clases regulares aumenta cada año. Este aumento tiene consecuencias para los maestros, que deben administrar las aulas para satisfacer las diversas necesidades y características de los estudiantes. El factor que contribuye a una educación inclusiva exitosa es la autoeficacia de los maestros para practicarla. Por otro lado, la implementación exitosa de la educación inclusiva y el rendimiento en la gestión del aula se ven influenciados por la medida en que los docentes participan en su trabajo, es decir, el "compromiso" de los docentes.

Método. Este estudio correlacional cuantitativo tuvo como objetivo determinar si el compromiso de los docentes media la autoeficacia en la práctica inclusiva y la gestión del aula. Un total de 242 maestros de escuela primaria inclusivos en DKI Yakarta-Indonesia, completaron tres cuestionarios de autoinforme.

Resultados. El compromiso de los docentes actúa significativamente como mediador en la correlación entre la autoeficacia de los docentes y la administración de su aula.

Discusión y Conclusion: Utilizando el proceso motivacional en el modelo de demanda de trabajo, los resultados muestran que las funciones de autoeficacia de los docentes son un recurso personal para implementar la educación inclusiva. Esto significa que la autoeficacia de los maestros es realizada por la condición del maestro involucrado en el rol del trabajo, antes de influir finalmente en la medida en que el maestro maneja el aula. Por lo tanto, el estudiante en general, incluidos los estudiantes con necesidades especiales, obtienen los beneficios educativos óptimos.

Palabras clave: gestión del aula; educación inclusiva; escuela primaria; autoeficacia; compromiso del maestro. 


\section{Introduction}

Since the 1990 conference Education for All and Salamanca's follow-up statement in 1994, significant progress has been made toward inclusive education (United Nations Educational Scientific and Cultural Organization, 2009). In fact, those two movements became the global foundation for today's inclusive education, when separation for special needs students came to be considered a violation of educational rights (Kilanowski-press, Foote, \& Rinaldo, 2010; Fisher, Roach, \& Frey, 2002). Indeed, inclusive education is rooted in the social issue that demands justice and the right to education. Certainly, a shift in perception has occurred. Inclusive education that aims to accommodate special needs students has become a new trend in education. Since this type of education has been implemented in many countries, studies have shown some promising results. Dessemontet, Bless, and Morin (2012) stated that special needs student in general education classroom with support show slighly mote progress in literacy skills than children attending special school. Pawlowicz (2001) also stated that special needs students in inclusive classes show higher attendance rates, better academic performance, and greater social skills.

The implementation of inclusive education is important not only for special needs students but also for students in general, to align the school's climate with equality in society and the appreciation of differences. Unsurprisingly, the numbers of special needs students in regular schools have increased greatly. Data from the United States National Center for Education Statistics (2013) recorded the growth of regular schools in numbers of special needs students at $32 \%$ from 1989 to 2013 . According to data from Ministry of Education and Culture Republic of Indonesia (Kemendikbud), through 2016, Indonesia had 31,724 inclusive schools, with 23,195 at the primary level, 5660 at the junior high level, and 2869 at the senior high level (Maulipaksi, 2017). Kemendikbud recorded also that 159,002 special needs students received inclusive education and predicted that this number will continue to rise (Maulipaksi, 2017).

Even though inclusive education sounds promising for special needs students, teachers report other consequences: diversity of needs and of specialization creates more heterogenous classes. Consequently, teachers must pay more attention to classroom management before classes begin. Certainly, the quality of inclusive education is determined not only by placing special needs students in regular classrooms, but also by teachers' ability to create a 
supportive class environment that stimulates the students' potential and provides maximum learning opportunities (Soodak, 2003). For special needs students, the classroom functions as more than just a learning context. It becomes a mini-society where they can interact with others (Putte \& Schauwer, 2013) and accepted within the school community (Sofwan, Mujiyati, \& Hendrowati, 2019). Of course, effective learning and teaching processes cannot be achieved in a poorly managed classroom (Marzano, Marzano, \& Pickering, 2003).

Classroom management, seen as a "critical part of educational psychology" (Emmer \& Stough, 2001), can be defined as a teacher's effort to shape attitudes, arrange times, and provide attention through positive interaction with students (Pianta, Hamre, \& Allen, 2012). In fact, a recent study showed that classroom management is a top priority variable within another 228 variables that play significant roles in student achievement (Marzano \& Marzano in Farooq, 2011). Research finding that superior classroom management makes students feel accepted, secure, and supported. In addition, it creates an effect on teachers also (Soodak, 2013). Poor teacher's skill to organize their classroom can hinder the learning and teaching process, eventually becoming a source of teacher stress, burnout, and disappointment (Yamani, 2014). Therefore, the current study addresses three factors of classroom management: (1) behavioral management, which focuses on teachers' ability to use a variety of methods as preventive tools to elicit desired behaviors; (2) productivity, which focuses on teachers' ability to regulate time and learning routines; and (3) formatted instructional learning, which focuses on teachers' ability to maximize all the students' learning involvement by preparing a creative and fun learning process (Pianta et al., 2012).

The teachers' success in implementing classroom management that generates successful inclusive education is connected highly to their self-efficacy (Zee \& Komen, 2016). Study found that self-efficacy most strongly predicts teachers' acceptance of special needs students (Park, Dimitrov, Das, \& Gichuru, 2016). Teachers with high self-efficacy have better teaching performance for special needs students, higher responsibility in dealing with students' difficulties, and positive attitudes toward implementation of inclusive education and their students' characteristics (Park et al., 2016; Soodak, 2003; Savolainen, Malinen, \& Schwab, 2020). Self-efficacy can be defined as teachers' belief in their ability to decide the best way to affect their students' learning process positively (Lamorey \& Wilcox, 2005; Wangid, Mustadi, \& Mokshien, 2020). Aligned with educational trends and sensitive self-efficacy in context, experts in this field developed the teachers' self-efficacy concept in inclusive education. In 
practice, self-efficacy in inclusive education is defined as teachers' belief in their ability to modify instruction to meet their students' needs, in avoiding and controlling the annoyance of misbehaving students, and in creating good collaboration with their colleagues and the students' parents to provide learning for every student (Loreman, Sharma, \& Forlin, 2012). In inclusive education practice, self-efficacy involves three dimensions, with each representing a specific aspect of teaching inclusive classes: first, the efficacy to use inclusive instruction; second, efficacy in managing behavior; and third, efficacy in collaboration. In fact, research on teachers' self-efficacy did not point directly to the learning process in general, but to teachers' efficacy about their beliefs in implementing inclusive education and also to their classroom management.

On the other hand, classroom management as implemented by teachers can be reviewed as a key performance indicator, in order to know the teachers' actual involvement in teaching, in other words, their "engagement". In 1990, Khan introduced the concept of engagement, but at first, it was more popular in the context of industry and organizational psychology and known as "work engagement." As the engagement concept continued to develop in education, Klassen, Yerdelen, and Durksen (2013) tried to distinguish teachers' specific characteristics from other professions, finding that teachers need to develop positive relationships with students and colleagues (Klassen et al., 2013).

Fully engaged teachers are involved not only physically, but also emotionally and cognitively in their teaching. Their level of involvement in those three aspects-physical, emotional, and cognitive-elicits perceived energy to stimulate students to be more dedicated in their work (Alzyoud et al., 2015). Thus, teachers' engagement is defined as self-expression to present their personal being physically, cognitively, and emotionally, in order to execute their role as teachers optimally.

\section{Objectives and Hypotheses}

Theoritically, this study used the job-demand resources model from Schaufeli and Bakker (2004) for summarizes the interaction among those three aspects. The "work engagement" model (Figure 1), mentioned previously, uses the term "personal resource," indicating a resource owned by someone physically, psychologically, and socially, as well as by an organization that can stimulate energy for accomplishments, improvements, and self-study (Bakker \& Bal, 2010). Personal resource serves as intrinsic motivation because it can sustain 
the basic needs of autonomy, relatedness, and competence (Baker \& Bal, 2010). Individuals with good personal resources can activate their motivational process, in turn, can raise them to higher levels of performance engagement. Engagement in the job-demand resource plays a vital role as mediator between one's personal resource and work performance. In other words, the higher the personal resource, the higher the engagement level in the job is, hence producing good work output. The job-demand resource model by Schaufeli and Bakker (2004) has been implemented widely in industrial and organizational contexts, so adapting it to the educational context will be interesting.

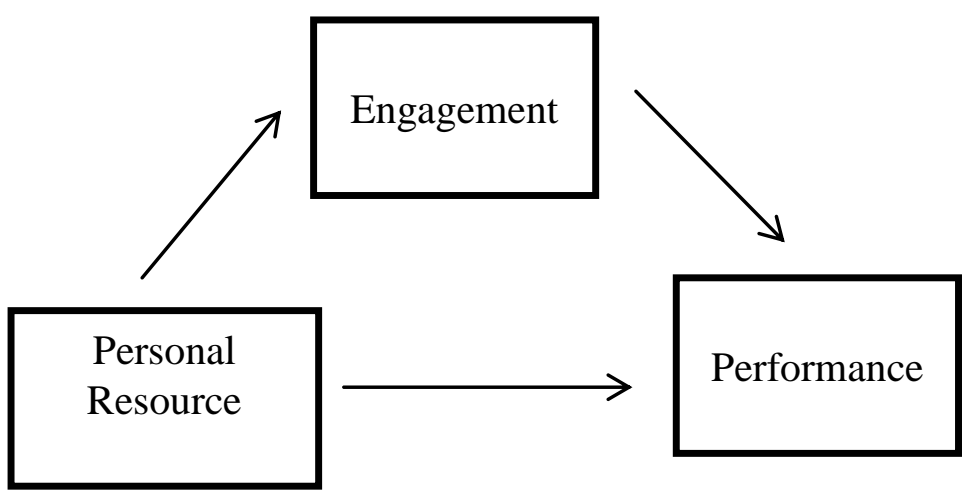

Figure 1. Job-demand Resource Model

To adapt the job-demand resource model to education, this research was conducted at the primary level, which has the most crowded tendencies, characteristics, complexity, and potential to create discomfort if activities take place simultaneously (Farooq 2011; Moore 2007). The development theory describes primary level as the crucial time when children move to the greater, more complex social context (Miller, 2011). Therefore, primary school teachers need to be more competent than others in classroom management are in order to construct an environment that is conducive to learning (Farooq, 2011). As the key factor in successful education, teachers need to have self-efficacy in implementing inclusive education, which presents some new challenges, especially that of good classroom management for all students. Besides that factor, another for successful education in classroom management acts as a key indicator of teachers' levels of engagement in their work. This study emphasized of examining the role of mediator because the center of research can focus on the mediation process as a basis for understanding the mechanism of relationship between two variables. Therefore, using the job-demand resource model this study aims to discover whether, in inclusive education, teachers' engagement acts as a mediator of their self-efficacy and classroom management. 


\section{Method}

\section{Participants}

This study was used the purposive sampling method to recruit 242 teacher-participants from 20 inclusive primary schools all over DKI Jakarta. Of these participants, $11.6 \%$ was taught in private primary schools; $83.1 \%$ are women and $16.9 \%$ are men. Their level of education is dominated by bachelor degrees, at $95.5 \%$. Table 1 summarizes their demographic data.

Table 1. Respondent Demographics $(N=242)$

\begin{tabular}{llcc}
\hline Demographic Variables & & $N$ & $\%$ \\
\hline Gender & Male & 41 & 16.9 \\
& Female & 201 & 83.1 \\
Education & High & & \\
& School & 2 & 0.8 \\
& Diploma & 1 & 0.4 \\
& & & \\
& Bachelor's & & 95.5 \\
& Degree & 231 & \\
Type of School & Master's & & 3.3 \\
& Degree & 8 & 88.4 \\
& Public & 214 & 11.6 \\
\hline
\end{tabular}

\section{Instruments}

Data were obtained from the questionnaires that measured 1) classroom management, 2) self-efficacy in inclusive practice, and 3) teachers' engagement. All three instruments were adapted into Bahasa.

Classroom management was measured by an instrument developed by Kurniawati et al. (Maulia, 2016), which refers to classroom management as defined by Pianta et al. (2012), and measure three dimensions : behavior management $(\mathrm{n}=6$, e.g: every new academic year, $I$ assist students in creating classroom rules and consequences), productivity ( $\mathrm{n}=4$, e.g: when the bell rang, every student, including students with special needs should enter classroom and 
occupy each seat in an orderly manner), and learning format $(\mathrm{n}=2$, e.g: I allow students with special needs to use various learning resources which are available like books, props, computer, etc ), with a total 12 items in the form of self-response. All items are favorable and use a four-point Likert scale ranged from 1 to $4(1=$ absolutely inappropriate, 4 = absolutely appropriate). The instrument produced Cronbach's alpha reliability coefficients of .90 .

Teachers' self-efficacy in inclusive practice was measured by an instrument adapted from the Teacher Efficacy in Inclusive Practice by Loreman et al. (2012). This instrument measures three dimensions: efficacy to use inclusive instruction $(n=7$, e.g: I can use a variety of assessment strategies, for example, portfolio assessment, modified tests, performancebased assessment, etc), efficacy in managing behavior $(\mathrm{n}=5$, e.g: I can control disruptive behavior in the classroom), and efficacy in collaboration $(\mathrm{n}=6$, e.g: I am able to work jointly with other professionals and staff to teach special needs student in the classroom), with 18 items in the form of a self-report. All items are favorable and use a four-point Likert scale ranged from 1 to 4 ( 1 = absolutely inappropriate, $4=$ absolutely appropriate). The instrument produced Cronbach's alpha reliability coefficients of .92 .

Teachers' engagement was measured by an instrument adapted from the Engaged Teachers Scale by Klassen et al. (2013). This instrument measures four dimensions: cognitive engagement ( $\mathrm{n}=10$, e.g: while teaching, I really "throw" myself into my work), emotional engagement ( $\mathrm{n}=12$, e.g: I found teaching fun), social engagement with students $(\mathrm{n}=12$, e.g: in class, I am aware of my students 'feelings), and social engagement with colleagues ( $\mathrm{n}=12$, e.g: at school, I connect well with my colleagues), with 46 items in the form of a self-report. All items are favorable and use a four-point Likert scale ranged from 1 to 4 ( 1 = absolutely inappropriate, 4 = absolutely appropriate). The instrument produced Cronbach's alpha reliability coefficients of .97 .

\section{Procedure}

Before conducting data, the researcher obtained a study permit from the principals to collect data through filling out the questionnaire in the designated school. Participants then were asked their willingness to participate in this study and were provided with informed consent, which they completed before filling out the research questionnaires. All data and information obtained were confidential and would only be used for research purpose only. 
Reseracher also explains the procedure for filling out the quistionnaire and the estimated time it takes to complete the questionnaire.

\section{Data Analysis}

This research question is whether, in inclusive education, teachers' engagement acts as a mediator of their self-efficacy and classroom management. To answer the research question,we used the Hayes regression test to analyze the mediation model. We first examines the relationship between variables. Then, Hayes regression test was conducted by taking the jobdemand model which teachers' engagement act as mediator.

\section{Results}

Results of Pearson Product Moment on the three variables-classroom management, efficacy in inclusive practice, and engagement - showed a significant correlation (Table 2). Pearson's correlation coefficient shows that self-efficacy in inclusive practice correlates positively with teachers' engagement: $r=.62\left(R^{2}=.38, p<.01\right)$. The coefficient of determination suggests that teachers' self-efficacy in inclusive practice has an effect on teachers' engagement of $38 \%$. Furthermore, the results suggested a positive relationship between self-efficacy in inclusive practice and classroom management: $r=.46\left(R^{2}=.21, p<.01\right)$. The coefficient of determination shows also that teachers' self-efficacy in inclusive practice plays a significant role $(21 \%)$ in classroom management. Teachers' engagement correlated positively with their classroom management. The correlational value for that relationship is $r=.64\left(R^{2}=.40, \mathrm{p}<\right.$ .01 ), indicating that teachers' engagement significantly affects their classroom management, at $40 \%$.

Table 2. Mean, Standard Deviation and Correlation of Research Variables

\begin{tabular}{llccc}
\hline & $\mathrm{M}$ & $S D$ & 1 & 2 \\
\hline 1. Self-efficacy in Inclusive Practice & 3.12 & .58 & & \\
2. Teacher Engagement & 3.39 & .54 & $.62^{* *}$ & \\
3. Classroom Management & 3.26 & .60 & $.46^{* *}$ & $.64 * *$ \\
\hline
\end{tabular}

$\mathrm{N}=242, * * \mathrm{p}<.01$ 
Furthermore, the Hayes' regression analysis showed that self-efficacy in inclusive practice acts as an independent variable (X), and classroom management as a dependent variable (Y), while teachers' engagement is an intervening variable or a mediator (M). The Hayes' test was conducted to analyze those three variables in one model through four paths-a, b, c and c'to reveal whether teachers' engagement mediates self-efficacy in inclusive practice and classroom management.

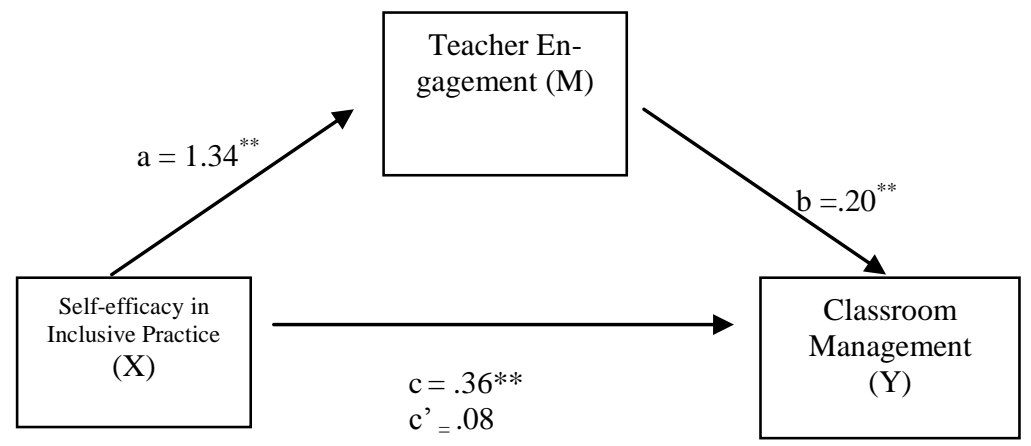

Figure 2. Regression coefficient between self-efficacy in inclusive practice and classroom management, mediated by teachers' engagement.

According to Figure 2, path a describes the correlation of self-efficacy in inclusive practice (X) with teachers' engagement (M), with the value coefficient $a=1.34, S E=.10, \mathrm{p}<$ .05. Path $b$ describes the correlation of teachers' engagement (M) with classroom management (Y), with the value coefficient $b=.20, S E=.02, \mathrm{p}<.05$. Path c describes the correlation between self-efficacy in inclusive practice (X) with classroom management (Y) without going through the teachers' engagement variable $(\mathrm{M})$, with the value of coefficient $c=.36, S E=.04$, $p<.05$. On the other hand, to reveal whether teachers' engagement plays a vital role as mediator, path c' describes the correlation of teachers' self-efficacy in inclusive practice (X) with classroom management $(\mathrm{Y})$ through the teachers' engagement variable $(\mathrm{M})$. This c' path produces the coefficient $c=.08, S E=.04, p<.05$.

\section{Discussion and conclusion}

The present study found a positive relationship among self-efficacy, classroom management, and teachers' engagement, based on data analysis of 242 inclusive primary level teachers' in DKI Jakarta. According to that result, self-efficacy and classroom management are related so closely as to be hardly separate, along with teachers' self-efficacy and engage- 
ment. These correlation results indicated that teachers' engagement is related closely to their classroom management.

Furthermore, the Hayes' regression analysis results showed that self-efficacy in inclusive practice plays a vital role as the predictor of engagement level (a path with $\beta_{a}=1.34, S E$ $=.109, p<.05)$. According to that result, teachers' self-efficacy in executing inclusive practice is a strong variable for providing teachers' good engagement and their ability to perform superior classroom management. Thus, self-efficacy predicts strongly teachers' ability to affect students' learning process and achieve the desired learning goal (Guskey \& Pasaro 1994). This result is important, especially for implementing inclusive education, which presents teachers with many challenges. However, this study shows that teachers' belief that they can handle and overcome such challenges can engage them more deeply in their profession. Theoretically, this result aligns with the argument of Bakker and Ball (2010), who stated that selfefficacy has a role as a personal resource that may spur greater achievement, provoke selfimprovement, and provide more energy for their professional practice. For these reasons, this study's result is a significant predictor of teacher engagement.

According to the Hayes' regression analysis, the $b$ path indicated that teachers' engagement condition significantly predicts their classroom management $\left(\beta_{b}=.205, S E=.022\right.$, $p<.05)$. This result affirms that of Bakker and Ball (2010), who stated that teachers' engagement is the most vital factor contributing to their performance. Another similar result comes from research by Bakker and Bal (2010) with 54 teachers in The Netherlands; the result stated that participants' level of work engagement could predict their quality of performance in a week. Myhre (2014) found also that individuals closely related to the engagement condition had feelings of energetic and effective association with their work activities and saw themselves as capable of dealing with the demands of their job.

Most interesting in the Hayes' regression result was the c path, which describes selfefficacy as a significant predictor of classroom management ( $c$ path with $\beta_{c}=.361, S E=.044$, $p<.05)$. However, it did not significantly predict classroom management when teachers' engagement variable is considered ( $c^{\prime}$ path with $\beta_{c^{\prime}}=.085, S E=.044, \mathrm{~ns}$ ). The Hayes' regression analysis showed that correlation between self-efficacy in inclusive practice and classroom management became insignificant in the presence of the engagement variable. Thus, the mediation model shows that teachers' belief about their ability to implement inclusive educa- 
tion does not correlate directly with classroom management. Nonetheless, it seems that there should be a condition in which teachers more deeply involved cognitively, emotionally, and socially with their profession before their self-efficacy in practicing inclusive system has a greater impact on classroom management.

Overall, the mediation model applied in this research is defined by the job-demand resource model suggested by Scaufeli and Bakker (2004). Through this model, satisfactory performance is assumed to be personal resource's output, mediated by teachers' engagement. In this research, the personal resource is teachers' self-efficacy in executing inclusive practice. Teachers' belief in their ability becomes the key factor in their classroom performance. This belief is also the strongest idea previously possessed by teachers (Henson, 2001). A study conducted by Lamorey and Wilcox in 2015 showed that having belief in their ability closely correlated with the amount of effort teachers were willing to put into the job and also with teachers' willingness to handle and overcome even the most difficult conditions. Moreover, another study conducted by Sandra in 2014 explained that in a challenging situation, teachers' self-efficacy plays a significant role in their personal resource's ability to overcome negative surroundings. All these elements are intensely relevant to inclusive education because its implementation has been perceived by many teachers as bringing new challenges (Soodak, 2003).

Undeniably, the application of inclusive education presents several challenges, for instance, concerns about changes in teaching responsibilities and issues related to teaching and learning activities (Soodak 2003; Kurniawati et al., 2012). Self-efficacy, in challenging situations, has a role as a personal resource to achieve the expected goal, in this case, to perform optimal classroom management. For instance, a good personal resource can function to motivate a teacher to higher levels of engagement. The greater the personal resource, the higher the engagement level in the job is. In turn, high engagement produces good working output. Schaufeli and Bakker (2004) argued that personal resource acts as energy that encourages individuals to invest more in their work. Thus, the personal resource serves as energy that drives one to engage in cognitive, emotional, and social activities. Engaging cognitively means the extent to which teachers seek to maximize their teaching performance, such as learning materials for teaching the next day, trying different teaching methods, or modifying student instruction. Emotionally, it means feeling positive about the teacher role, including pride in and enthusiasm for finding the new in teaching. Socially, teachers with good en- 
gagement conditions pursue relationships in their working environments, especially with students and colleagues. The teachers' involvement in these three aspects ultimately leads them to put more effort into classroom management.

This study's results support the Malinen (2013) argument, which stated that despite self-efficacy not being a new variable in education, it is still worth studying because of belief's strong influence on almost all aspects of teaching. The present study shows that selfefficacy is a significant resource for optimum teaching performance and certainly influences the success of inclusive education and the quality of education received by students with special needs (Park et al., 2016). The finding of teachers' engagement as a mediator contributes also to the urgency of engagement in the educational context, especially in inclusive education. Studies on teachers' engagement are already widely conducted. However, such studies are still limited to using work engagement constructions that ignore the teaching profession's distinctive characteristics. The argument of Klassen et al. (2012) that portrayed teachers' engagement in general, without further considering their engagement with their students, ignored the heart of teaching itself. Moreover, this study's results contribute to seeing teachers' engagement from the perspective of teacher as a "special profession" with typical teacher characteristics, namely teachers' social engagement with students and colleagues. This study emphasizes also the urgency of studying teacher engagement, as proposed by Konermann (2012), who distinguished at least two aspects of urgency. First, teachers are still the main implementers of education. The higher teachers' performance quality, the higher quality education students receive for their future. Teaching quality cannot be separated from the extent to which teachers engage in their work role. Second, teachers with a prominent level of engagement tend to have low intentions to leave the profession, to have several methods of engaging students in learning, and to focus on providing quality education manifested in classroom practice (Konermann, 2012).

Moreover, the present study has emphasized the mediator variable's importance. McKinnon (in Urbayatun \& Widhiarso 2012) argues that sometimes, the connection between two phenomena is not present in direct form but mediated by emergences of other phenomena first (Urbayatun \& Widhiarso, 2012). As found in this study that mechanism process that occurs between teachers' self-efficacy variables in practicing inclusive education does not relate directly to classroom management. However, a motivational process, through which teachers believe they can implement inclusive education, provides energy to become involved physi- 
cally, cognitively, emotionally, and socially in teaching students with various needs. Further study should explore in detail the variable that provides energy to personal resource. Regardless of the limitations, for example, using self-reports that risk answers based on social desirability, further study should avoid also contamination by answers with high social desirability, so data should be collected directly, in order to capture teachers' concrete behavior and attitude in conducting their classes.

This research was conducted by considering a great challenge facing by teachers in manage the inclusive practice in primary school. Inevitably, inclusive education's implementation will bring forth many challenges to teachers: concerns about responsibility and issues related to the learning and teaching process (Soodak, 2003). Thus, self-efficacy plays also a significant role in achieving desired goals through personal resources. In these terms, selfefficacy can be realized through optimal class management. Self-efficacy can be also seen as an agent of the personal resource that functions as energy for teachers to engage cognitively, emotionally, and socially with their jobs. The Principal or school stakeholders can pay more attention the development of teachers' self-efficacy by holding training on knowledge and skills about inclusion.

In this research, the results show that teachers' engagement acts significantly to mediate their self-efficacy and classroom management. Indeed, especially teachers' belief in their ability affects them directly. Practically, it is also suggested to the principal or school stakeholders to focus attention on the importance of teachers' belief in their abilities to execute inclusive practice, that is, to manage heterogeneous classes with a variety of educational needs. The more teachers are engaged, the more energy, time, and ability they invest in their profession. Eventually, their belief manifests in their attitude about managing classes optimally.

\section{References}

Alzyoud, A. A. Y., Othman, S. Z., \& Isa, M. F. M. (2014). Examining the role of job resources on work engagement in the academic setting. Asian Social Science, 11, 103. doi.org/10.5539/ass.v11n3p103. 
Bakker, A. B., \& Bal, P. M. (2010). Weekly work engagement and performance: A study among starting teachers. Journal of Occupational and Organizational Psychology, 83, 189-206.

Beaton, D. E., Bombardier, C., Guillemin, F., \& Ferraz, M. B. (2000). Guidelines for the process of cross-cultural adaptation of self-report measures. Spine, 25(24), 3186-3191. https://doi.org/10.1097/00007632-200012150-00014.

Dessemontet, R. S., Bless, G., \& Morin, D. (2012). Effects of inclusion on the academic achievement and adaptive behaviour of children with intellectual disabilities. Journal of Intellectual Disability Research, 56(6), 579-587.

Emmer, E. T., \& Stough, L. M. (2001). Classroom Management: a critical part of educational psychology, with implications for teacher education. Educational Psychologist, 36, 1-12.

Farooq, M. S. (2011). Perceptions of prospective teachers about factors influencing classroom management. Journal of Quality and Technology Management, VII, 23-38.

Fisher, D., Roach, V., \& Frey, N. (2002). Examining the general programmatic benefits of inclusive schools. International Journal of Inclusive Education, 6, 63-78.

Guskey, T.R., \& Passaro, P.D. (1994). Teacher efficacy: A study of construct dimensions. American Educational Research Journal, 31, 627-643.

Hayes, A. (2013). Introduction to Mediation, Moderation and Conditional Process Analysis: A Regression-based Approach. New York: The Guilford Press.

Kilanowski-press, L., Foote, C.J., \& Rinaldo, V.J. (2010). Inclusion classroom and teachers: A survey of current practice. International Journal of Special Education, 25(3), 43-56.

Klassen, R. M., Yerdelen, S., \& Durksen, T. L. (2013). Measuring teacher engagement: Development of the engaged teachers scale (ETS). Frontline Learning Research, 2, 33-52.

Konermann, J. (2012). Teachers' work engagement: A deeper understanding of the role of job and personal resources in relationship to work engagement, its antecedents, and its outcome. (Published Doctoral Dissertation). Retrieved from Research Universiteit Twente. doi:10.3990/1.9789036533027.

Kurniawati, F., Minnaert, A., Mangunsong, F., \& Ahmed, W. (2012). Empirical study on primary school teachers' attitudes towards inclusive education in Jakarta, Indonesia. Procedia Social and Behavioral Science, 69, 1430-1436.

Lamorey, S. \& Wilcox, J. (2005). Early interventionist self-efficacy scale: A measure and its applications. Early Childhood Research Quarterly, 20, 69-85.

Loreman, T., Sharma, U., \& Forlin, C. (2013). Do pre-service teachers feel ready to teach in inclusive classrooms? A four country study of teaching self-efficacy. Australian Journal of Teacher Education, 38, n1. doi: 10.14221/ajte.2013v38n1.10.

Malinen, O. (2013). Inclusive education from teachers' perspective: Examining pre and in service teachers' self-efficacy and attitudes in mainland China. Inclusive education from teachers' 
perspective. (Publish Doctoral Dissertation). Retrieved from UEF Electronic Publication. (UEF 978-952-61-1167-4).

Marzano, R.J., Marzano, J.S. \& Pickering, D. (2003). Classroom management that works: -Researchbased strategies for every teacher. Alexandria, VA: Association for Supervision and Curriculum Development.

Mäkinen, M. (2013). Becoming engaged in inclusive practices: Narrative reflections on teaching as descriptors of teachers' work engagement. Teaching and Teacher Education, 35, 51-61.

Maulia, M. (2016). Pendidikan Inklusif Di Sekolah Dasar: Hubungan Antara Sikap Guru Terhadap Universitas Indonesia Pendidikan Inklusif di Sekolah Dasar. (Unpublished Thesis). Universitas Indonesia, Depok.

Maulipaksi, D. (2017). Kementerian Pendidikan dan Kebudayaan : Sekolah Inklusi dan Pembangunan SLB Dukung Pendidikan Inklusi. Retreived from http://www.kemdikbud.go.id/main/blog/2017/02/sekolah-inklusi-dan-pembangunan-slbdukung-pendidikan-inklusi.

Miller, P.H. (2011). Theories of Developmental Psychology (5th ed.) -. USA: Worth Publisher

Moore, K.D. (2007). Classroom Teaching Skills. Boston: McGraw-Hill.

Moore, D.H. (2008). Analyzing relationships between classroom management strategies, student achievement scores, and teachers' attitudes and beliefs in diverse elementary settings. (Publish $\begin{array}{lll}\text { Doctoral Dissertation). } & \text { Retrieved }\end{array}$ https://search.proquest.com/openview/95e9f994b1d33bc75bd6e07158ec0df7/1?pqorigsite $=$ gscholar $\& \mathrm{cbl}=18750 \&$ diss $=\mathrm{y}$.

Pawlowicz, B. (2001). The effects of inclusion on general education students. (Published Thesis). Retreived from http://digital.library.wisc.edu/1793/40113.

Park, M., Dimitrov, D. M., Das, A., \& Gichuru, M. (2016). The teacher efficacy for inclusive practices (TEIP) scale: Dimensionality and factor structure. Journal of Research in Special Educational Needs, 16, 2-12.

Pianta, R.C., Hamre, B.K., \& Allen, J.P. (2012). Teacher-student relationships and engagement: Conceptualizing, measuring, and improving the capacity of classroom interactions. In S. L. Christenson, A.L Reschly, \& C. Wylie. (Eds.), Handbook of Research on Student Engagement (pp. 365-386).New York: Springer Science and Business Media.

Putte, I. \& Schauwer, E. (2013) Becoming a different teacher: Teachers perspective on Inclusive Education. Transylvanian Journal of Psychology, Special Issue, 245-263.

Robinson, C. (2011). The influence of student and school variables on student performance on the New Jersey Assessment of Skills and Knowledge in Grade 8. (Publish Doctoral Dissertation). Retrieved from https://scholarship.shu.edu/dissertations/1824. 
Savolainen, H., Malinen, O.-P., \& Schwab, S. (2020). Teacher efficacy predicts teachers' attitudes towards inclusion - a longitudinal cross-lagged analysis. Intemational Journal of Inclusive Education, 24(14), 1-15.https://oi.org/10.1080/13603116.2020.1752826.

Schaufeli, W.B., \& Bakker, A.B. (2004). Job demands, job resources, and their relationship with burnout and engagement: a multi-sample study. Journal of Organizational Behavior, 25(3), 293315 .

Sofwan, A., Mujiyati, \& Hendrowati, T. Y. (2019). Perceptions of Inclusion Education by Parents of Elementary School-Aged Children in Lampung, Indonesia. International Journal of Instruction, 12(1), 199-212. https://doi.org/10.29333/iji.2019.12113a.

Soodak, L. C. (2003). Classroom management in inclusive settings. Theory into Practice, 42(4), 327334.

United Nations Educational Scientific and Cultural Organizations. (2009). Policy guidelines on inclusion in education. Paris: Author.

Urbayatun, S., \& Widhiarso, W. (2012). Variabel mediator dan moderator dalam penelitian psikologi kesehatan masyarakat. Jurnal Psikologi, 39(2), 180-188.

Wangid, M. N., Mustadi, A., \& Mokshien, S. E. B. (2020). The exploration of teachers' efficacy in teaching: Comparative study in Indonesia and Malaysia. Cakrawala Pendidikan, 39(2), 257268. https://doi.org/10.21831/cp.v39i2.30012.

Yamani, S. (2014). Classroom management practice in inclusive classroom. (Published Master Thesis). Retrieved from Space Repository University of Toronto. (1807/67069).

Zee, M., \& Koomen, H. M. (2016). Teacher self-efficacy and its effects on classroom processes, student academic adjustment, and teacher well-being: A synthesis of 40 years of research. Review of Educational Research, 86(4), 981-1015.

Received: $29-04-2020$

Accepted: $24-12-2020$ 